\title{
Türkçe Öğretmeni Adaylarının Türkçe Dil Bilinç Düzeylerinin Belirlenmesi: Bir Karma Yöntem Araştırması
}

\author{
Bünyamin SARIKAYA ${ }^{1}$ ve Yunus ŞAKIROĞLU ${ }^{2}$
}

Öz

$\mathrm{Bu}$ araştırmada amaç, Türkçe öğretmeni adaylarının Türkçe dil bilinci düzeylerini çeşitli değişkenlere göre tespit etmek ve Türkçe dil bilinci ile ilgili görüşlerini belirlemektir. Çalışma, 4 farklı devlet üniversitesinde öğrenim gören 249 Türkçe öğretmeni adayı ile yürütülmüsstür. Çalışmada Türkçe öğretmeni adaylarının Türkçe dil bilinci durumlarının ne düzeyde olduğu, bu adayların Türkçe dil bilinci durumlarının cinsiyete, sınıf düzeylerine, anne-baba eğitim durumlarına göre değişip değişmediği tespit edilmiştir. Ayrıca Türkçe dil bilinci kavramının onlar için ne anlam ifade ettiği ve zaman ve teknolojinin ilerlemesiyle bireylerde Türkçe dil bilincinin zayıflayıp zayıflamayacağ konusunda ne düşündükleri sorulmuştur. Çalışmada karma yöntem kullanılmıştır. Veriler Yaman (2011) tarafindan geliştirilen "Türkçe Bilinci Ölçeği” ve araştırmacıların geliştirdikleri Görüş Alma Formu ile toplanmıştır. Çalışma sonucunda Türkçe öğretmeni adaylarının Türkçe dil bilinci düzeylerinin "yüksek" olduğu ve cinsiyet, anne, baba eğitim durumlarına göre farklılaşmadığ1 ancak sınıf düzeyine göre farklılaştığ1 tespit edilmiştir. Ayrıca Türkçe öğretmeni adaylarından alınan görüşler doğrultusunda Türkçe dil bilinci kavramının kendileri için farklı anlamlara geldiği ve Türkçe öğretmeni adaylarının büyük çoğunluğunun zaman ve teknolojinin ilerlemesiyle bireylerde Türkçe dil bilincinin zayıflayacağını düşündüğü de saptanmıştır. Çalışma alan yazın doğrultusunda tartışılmış ve öneriler sunularak bitirilmiştir.

Anabtar Sözcükler: Türkçe, dil, dil bilinci, Türkçe dil bilinci

Determining Preservice Turkish Teachers' Awareness of Turkish Language: A MixedMethod Study

\begin{abstract}
This study investigated preservice Turkish teachers' awareness of the Turkish language based on different variables and looked into their views on the topic. The sample consisted of 249 preservice Turkish teachers from four public universities. This study determined how aware participants were of Turkish and whether their views depended on gender, grade level, and parents' education. The study also addressed what the concept of "Turkish language awareness" meant to them and whether they thought time and advances in technology would make people less and less aware of Turkish. The study adopted a mixed research design. Data were collected using an Opinion Form developed by the researchers and the Turkish Consciousness Scale developed by Yaman (2011). The results showed that participants were highly aware of Turkish and that their awareness did not depend on gender and parents' education levels. However, their awareness of Turkish depended on grade level. Moreover, participants stated that the concept of "Turkish language awareness" meant different things to them. Most participants believed that people would become less and less aware of Turkish with time and advances in technology. The results were discussed based on the literature, and recommendations were made.
\end{abstract}

Key Words: Turkish, language, language awareness, Turkish language awareness

\section{Atıf İçin / Please Cite As:}

Sarıkaya, B. ve Şakiroğlu, Y. (2021). Türkçe öğretmeni adaylarının Türkçe dil bilinç düzeylerinin belirlenmesi: Bir karma yöntem araştırması. Manas Sosyal Araștırmalar Dergisi, 10(ÖS), 40-52.

\footnotetext{
${ }^{1}$ Doç. Dr. - Muş Alparslan Üniversitesi Eğitim Fakültesi, b.sarikaya@alparslan.edu.tr

(iD ORCID: 0000-0002-8393-7127

2 Arş. Gör. - Muş Alparslan Üniversitesi Eğitim Fakültesi, y.sakiroglu@alparslan.edu.tr

(D) ORCID: 0000-0001-6151-7984
} 


\section{Giriş}

Dil, sözcüklerin mantıksal bir örüntü ile arka arkaya sıralanmasıdır. "Dil, insanların bilgi, duygu, düşünce ve isteklerini ifade etmek ve aynı zamanda başkalarının bilgi, duygu, düşünce ve isteklerini öğrenmesi için kullanılan ve belli becerileri kazanmayı gerektiren bir sistemdir" (Aydeniz ve Haydaroğlu, 2021, s. 202). Her dil, evreni kendine göre duyumsar ve kendine özgü bir şekilde yorumlar. İnsanoğlu, anlam evrenini ana dili vasıtasıyla yaptığı duyumsal, düşünsel, bildirimsel ve duygusal alışverişlerle inşa eder. Ana dili hissi, bebeklik ile başlar ve bilincini/bilinçaltını çevreleyerek ömrü boyunca gelişir (Adalı, 1983; Özdemir, 1983; Kırkkılıç ve Ulaş, 2003).

Toplumların kültürel birikimlerini nesilden nesile aktaran, onları birbirlerinden farklı yapan ve basit insan toplulukları olmaktan kurtaran dil; bir milletin var oluş kaynağı ve var olma sebebidir (Kaplan, 1996; Sever, 2001). Zira her şey dilde kendini bulur (Temizyürek, 2008). Dil; insanların dünyaya geldiği andan itibaren içinde bulunduğu topluma uyum sağlamasını, o toplumun değer ve değer yargilarını anlayıp hayatını bu yönde devam ettirmesini, diğer bireylerle sağlıklı şekilde iletişime geçebilmesini sağlayan en önemli araçlardan biridir (Yaman, 2011; Göçer, 2013). Toplumsal yaşantımızda büyük öneme sahip olan dil; günümüzde küreselleşme, sosyo-kültürel, siyasi, bilimsel ve teknolojik gelişme ve değişmelerden önemli ölçüde etkilenmektedir.

Devamlı gelişen, canlı bir varlık olan dilin gelişimini etkileyen etmenlere bakmak gerekir. Bu bağlamda dili etkileyen etmenler kısaca "1. Kültürel gelişmeler 2. Ekonomik gelişmeler 3. Teknolojik gelişmeler 4. Siyasî gelişmeler 5. Sosyal gelişmeler" (Demirbağ, 2002, s. 126) olarak sıralanabilir. Dil farkındalığ ya da dil duyarlıllğı olarak da ifade edilen dil bilincinin, dili etkileyen etmenlerden bağımsız olarak oluşması ve gelişmesi büyük önem arz etmektedir.

Bilinç kelimesi, Büyük Türkçe Sözlükte (TDK, 2020) “insanın kendisini ve çevresini tanıma yeteneği; temel bilgi, temel görüş; alg1 ve bilgilerin zihinde duru ve aydınlık olarak izlenme süreci, şuur" şeklinde tanımlanmaktadır. Dil bilinci ise "bireyin kullandığı dile ve bu dilin kullanım alanlarına ilişkin duyarlılı̆̆ı" (Erdem ve Eskimen, 2019, s. 24) olarak tanımlanabilir. Dil bilinci, bireysel olarak bilinçli olmanın yanı sıra toplumsal bir bilinci de gerektirir. Zira "toplumların ortak bilincinde (kolektif bilinç) dilin yaratıcı bir rolü vardır. Humboldt’a göre toplumların dünya görüşleri, dillerinden farklı olamayacaktır. Gerçekten de her dil kendi dünyasını inşa eder. Toplumların hayata dair tasavvurları, hayatı algılayışları dille ifadesini bulurken dilin kendisi de bu anlayıştan bağımsız değildir”" (Eryılmaz, 2017, s. 2).

Sağlıklı bir iletişimin yolu dili iyi kullanmaktan geçer. Bunun için de iyi bir dil bilincine sahip olmak gerekmektedir. Dil öğretmenin, özellikle ana dili öğretmenin ilk ve en önemli ön koşulu iyi bir dil bilincine sahip olmaktır. Dil öğreticilerinin bu ön koşulu sağlayacak donanım ve duyarlllığa sahip olmaları büyük önem arz etmektedir. Birey, var olma sebeplerinden biri olan ana diline karşı duyarlı olmalıdır. Zira bireyin yaşamı boyunca kullanacağı dile karşı meydana gelen duyarsızlıklar, dile büyük ölçüde zarar verir. Bu da dilde yozlaşmaya, önemini kaybetmeye ve sonucunda ölü diller arasına katılmaya neden olabilir (Bulut ve Coşkun, 2020, s. 1131).

Dil bilincine sahip birey, dilini doğru kullanmaya itina gösterir ve buna bağlı olarak hem dilini korur hem de dilinin sağlıklı bir biçimde gelişmesine katkı sunar. "Dilin kusurlu olması bireylerin dil eksikliğinden kaynaklanan bir durumdur. Dilin kuralların, inceliklerini yeterince bilen bireyler dili daha etkili ve güzel kullanır" (Gövsa, 2005 Akt: İpek, 2015, s. 35).

Alanyazında yapılan bazı araştırmalarda, dil bilinci yüksek olan kişilerin dili öğrenme süreçlerinde çok daha başar1 gösterdiği tespit edilmiştir (Leow 1997; Rosa ve O’Neill 1999; Abu Radwan, 2005; Robinson 2005). Bir başka çalışmada ise, dili üst seviyelerde kullanan bireylerin kendi dil farkındalıklarını da arttırdıkları sonucuna ulaşılmıştır (Gass vd., 2003). Borg (1994 Akt: Erdem ve Eskimen, 2019, s. 25) dil bilinci yüksek kişilerin diğer bireylerden aşağıdaki özellikler bakımından daha avantajlı olduğunu ifade etmiştir:

1. Dil bilinci yüksek kişiler, dili yaşayan ve gelişebilen bir olgu olarak algilarlar ve onu çok yönlü olarak kullanabilirler.

2. Dil bilinci yüksek kişiler, ana dili ve diğer diller arasında çözümlemelere ve karşılaştırmalara dayanan konuşmalar yapabilirler.

3. Dil bilincine sahip öğrenenler, inceleme ve keşfetmeyi bir gereklilik olarak görürler. 
4. Dil becerilerini geliştirmeyi aynı zamanda anlamlandırmayı amaçlarlar.

5. Dil bilinci yüksek kişiler, bilişsel ve duyuşsal düzeye yükselmeyi hedeflerler.

Ülkemizde Türkçeye karşı gösterilen duyarsız tutumun ve sorunların temelinde yeni kuşaklara iyi bir Türkçe eğitimi verilmemesi yatmaktadır. "Bir toplum ki, bireyleri kendi ana dilini doğru konuşup yazamaz, doğru dürüst bir eğitimden yoksundur- çünkü öğretecek olan kişinin kendisi bilmiyor-peki o toplum nasıl kalkınacak ve nasıl çağdaş uygarlık düzeyine ulaşacaktır” (Ateş, 2010, s. 18). "Öğgretmen anadili bilincine ve duyarlılığına sahipse anadilinin bütün inceliklerini kullanarak öğrencisine model olabilir ve bu sevgiyi, bilinci, duyarlılı̆̆1 öğrencilerinde oluşturabilir. Sahip olunmayan duyarlılık ve bilincin aktarılması söz konusu değildir" (Kolaç, 2008, s. 442). Bu konudaki en büyük sorumluluk öğretmen yetiştiren eğitim kurumlarına düşmektedir. Branş ayırmaksızın tüm öğretmen ve öğreticiler Türkçeyi doğru ve kurallara uygun kullanabilmeli, öğrencilerine Türkçeyi kullanmalarında bu anlamda önayak olmalıdırlar. Türkçenin bilinçli bir biçimde kullanılabilmesi ve yabancı dillerin tehditlerinden korunması için Türkçeyi kullanan, öğreten ve öğrenenlerin dili kullanım bilincine sahip olmaları hayati derecede önem arz etmektedir. “Öğretmen anadili bilincine ve duyarlılı̆̆ına sahipse anadilinin bütün inceliklerini kullanarak öğrencisine model olabilir ve bu sevgiyi, bilinci, duyarlılı̆̆1 öğrencilerinde oluşturabilir. Sahip olunmayan duyarlılık ve bilincin aktarılması söz konusu değildir" (Kolaç, 2008). Bu anlamda Türkçe öğretmenleri, temel sorumluluklarının farkında olmalıdırlar ve bu öğretmenlerin yetiştikleri kurumlarda öğrenim gören Türkçe öğretmeni adaylarından da aynı sorumlu tavır beklenmelidir (Tekşan ve Kanık Uysal, 2018, s. 267).

Alanyazın incelendiğinde, dil bilinci ve Türkçe dil bilinci hakkında yapılan çalışmaların olduğu ve bunların çok az kısmının Türkçe dil bilinci ile ilgili olduğu saptanmıştır. Ana dili bilincinin ortaokullarda kazandırılmasının amaçlandığı (Baskın ve Demir, 2017); bireylerde dil bilincinin ele alındığ1 (İpek, 2015); Türkçe ve Türk Dili ve Edebiyatı öğretmeni adaylarının dil bilinci düzeylerinin incelendiği (Arslan ve Kılıç, 2012; Tekşan ve Kanık Uysal, 2018; Erdem ve Eskimen, 2019; Bulut ve Coşkun, 2020); üniversite öğretim elemanlarının dil bilinci ve Türkçe kullanım duyarlılı̆̆ının araştırıldı̆̆ı (Kızıltan ve Yangın Ersanlı, 2008); sözcük öğretimi yoluyla ortaokullarda Türkçe dil bilincinin incelendiği (Demir, 2016); Eski Türk Edebiyatında Türk dili bilincinin konu alındığı (Taşkesenlioğlu, 2020); kuşaklararası karşılaştırmanın yapıldığı (Şenyuva vd., 2017) çalışmalar bulunmaktadır. Ancak Türkçe öğretmeni adaylarının Türkçe dil bilinç düzeylerinin belirlenmesinde karma yöntem araştırmasının yapıldı̆̆ı herhangi bir çalışmaya rastlanmamıştır. Çalışmanın bu yönüyle alanyazına katkıda bulunması hedeflenmektedir.

Bu araştırmada amaç, Türkçe öğretmeni adaylarının Türkçe dil bilinci düzeylerini çeşitli değişkenlere göre tespit etmek ve Türkçe dil bilinci ile ilgili görüşlerini belirlemektir. Araştırmanın alt problemleri aşağıda yazılan şekilde oluşturulmuştur:

1. Türkçe öğretmeni adaylarının Türkçe dil bilinci durumları ne düzeydedir?

2. Türkçe öğretmeni adaylarının Türkçe dil bilinci durumları cinsiyete göre değişmekte midir?

3. Türkçe öğretmeni adaylarının Türkçe dil bilinci durumları sınıfa göre değişmekte midir?

4. Türkçe öğretmeni adaylarının Türkçe dil bilinci durumları anne eğitim durumuna göre değişmekte midir?

5. Türkçe öğretmeni adaylarının Türkçe dil bilinci durumları baba eğitim durumuna göre değişmekte midir?

6. Türkçe dil bilinci kavramı sizin için ne anlam ifade ediyor?

7. Zaman ve teknolojinin ilerlemesiyle bireylerde Türkçe dil bilincinin zayıflayacağını düşünüyor musunuz? Neden?

\section{Yöntem}

\section{Araştırma Modeli}

Araştırmada, karma araştırma yöntemi kullanılmıştır. Bu yöntemde nitel ve nicel veriler birlikte ya da sıralı olarak toplanıp analiz edilmektedir (Creswell ve Plano Clark, 2014). Araştırmanın nicel boyutunda nicel araştırma tekniklerinden tarama modeli uygulanmıştır. Araştırmanın nitel boyutunda ise görüşme yöntemi uygulanmıştır. Görüşme için yarı yapılandırılmış sorulardan oluşan ve araştırmacılar tarafından geliştirilen görüşme formu kullanılmıştır. Elde edilen veriler, içerik analizi yöntemi ile analiz edilmiştir. 


\section{Çalışma Grubu}

$\mathrm{Bu}$ araştırmanın çalışma grubunu 2020-2021 öğretim yllı bahar döneminde 4 farklı devlet üniversitesinde öğrenim gören Türkçe öğretmeni adayları oluşturmaktadır. Çalışma grubu 182 kadın, 67 erkek Türkçe öğretmeni adayından oluşmaktadır. Çalışmaya katılım konusunda gönüllülük esas alınmıştır.

\section{Veri Toplama Araçları}

Çalışmada 2 farklı veri toplama aracı kullanılmıştır. Nicel verilerin toplanmasında Yaman (2011) tarafindan geliştirilen ve 17 sorudan oluşan "Türkçe Bilinci Ölçeği” kullanılmıştır. Geçerliliği ve güvenirliğ̣i sağlanan ölçek 5'li likert hazırlanmıştır. Ölçekten alınabilecek en yüksek puan 85, en düşük puan ise 17'dir. Ölçekten alınan yüksek puan Türkçe dil bilinci düzeyinin yüksek olduğunu, düşük puan ise Türkçe dil bilincinin zayıf olduğunu göstermektedir. Yazar tarafindan yapılan çalışmada ölçeğin iç tutarlılık katsayısı (Cronbach Alpha) ,88 bulunurken (Yaman, 2011) bu çalışma için ölçeğin iç tutarllılk katsayısı (Cronbach Alpha), 89 olarak bulunmuştur.

Nitel verilerin toplanmasında ise araştırmacılar tarafindan geliştirilen "Görüşme Formu" kullanılmışır. Formun hazırlanması aşamasında alan yazın detaylı bir şekilde incelenmiş ve bir soru havuzu oluşturulmuştur. Hazırlanan form 3 Türkçe Eğitimi alan uzmanının görüş ve önerilerine sunulmuştur. Uzmanlardan gelen dönütler 1şı̆̆ında görüşme formuna son şekli verilmiştir.

\section{Verilerin Toplanmas1}

Araştırma kapsamında çalışma grubunda yer alan Türkçe öğretmeni adaylarına ölçme araçları pandemi dolayısıyla elektronik sistem üzerinden ulaştırılmıştır. Ölçme araçları, Google Formlar ve e-posta aracılığıyla gönderilmiştir. Bu süreçte araştırmacılar Türkçe öğretmeni adaylarıyla görüşme halinde olmuş ve anlaşılmayan hususlar olduğunda kendilerine gerekli açıklamaları yapmışlardır.

\section{Verilerin Analizi}

Çalışmada nicel verilerin analizi yapilırken elde edilen ölçek formları SPSS 21 paket programı aracılığıyla analiz edilmiştir. Analiz yapılmadan önce Cronbach's Alpha aracıllğıyla verilerin güvenirliğine bakılmıştır. Bu çalışmada güvenirlik ,89 çıkmıştır. Ayrıca normallik testi yapılmış, verilerin normal dağıldığ1 görülmüş, bu nedenle analiz için parametrik testlerden t-Testi ve Tek Yönlü Varyans Analizi olan One Way Anova Testi kullanılmıştır.

Nitel verilerin analizinde ise nitel çözümleme tekniklerinden içerik analizinden yararlanılmıştır. "İçerik analizinde temelde yapılan işlem, birbirine benzeyen verileri belirli kavramlar ve temalar çerçevesinde bir araya getirmek ve bunları okuyucunun anlayabileceği bir biçimde organize ederek yorumlamaktır" (Yıldırım ve Şimşek, 2006).

İçerik analizi yapılırken verilerdeki temaların tespit edilmesi, verilerin temalara göre ayrılması, bulguların değerlendirilmesi/yorumlanması aşamaları izlenmiştir. Araştırmada, Türkçe öğretmeni adaylarının görüşlerinden örnek cümleler de verilmiştir. Araştırmanın güvenirliğini arttırmak için Türkçe öğretmeni adaylarının cümlelerinden doğrudan alıntılara yer verilmiştir. Alıntıların hangi Türkçe öğretmeni adayına ait olduğunu belirtmek için her alıntının sonunda K1, K2... biçiminde kodlama yoluna gidilmiştir.

\section{Bulgular}

Çalışmada ulaşlan bulgular alt problemler bağlamında sunulmuştur.

\section{Birinci Alt Probleme Yönelik Bulgular}

Çalışmanın birinci alt problemi, Türkşe ögrretmeni adaylarmm Türkse dil bilincinin ne durumda olduğuna ilişkindir. Buna yönelik bulgular Tablo 1'de yer almaktadır.

Tablo 1. Türkşe Öğretmeni Adaylarmmn Türkşe Dil Bilinciyle İlgili Betimsel İstatistikler

\begin{tabular}{ccccc}
\hline & $\mathbf{N}$ & $\overline{\mathbf{X}}$ & $\mathbf{S}$ & Anlamı \\
\hline \multirow{2}{*}{ Toplam } & 249 & 64,88 & \multirow{2}{*}{11,58} & $\begin{array}{c}\text { Çoğu zaman } \\
\text { katıliyorum (yüksek) }\end{array}$ \\
\hline
\end{tabular}

Tablo 1'de Türkçe öğretmeni adaylarının Türkçe dil bilinci ile ilgili betimsel istatistikleri yer almaktadır. Buna göre ölçekten alınacak en yüksek puanın 85, en düşük puanın ise 17 olduğu düşünüldüğünde öğretmen adaylarının Türkçe dil bilinci ortalamalarının 85 üzerinden 64,88; 5 üzerinden 
ise 3,76 ortalamaya karşıllk geldiği görülmektedir. Dolayısıyla bu değerin "çoğu zaman katılıyorum" seçeneğine denk geldiği ve "yüksek" olduğu tespit edilmiştir.

\section{İkinci Alt Probleme Yönelik Bulgular}

Çalışmanın ikinci alt problemi, Türkse ögretmeni adaylarmm Türkşe dil bilincinin cinsiyete göre farkhlilaş̨p farkhlaş̧madı̆ğna ilişkindir. Buna yönelik bulgular Tablo 2'de yer almaktadır.

Tablo 2. Türkse Öğretmeni Adaylarmmn Cinsiyete Göre Türkçe Dil Bilinci Arasındaki Farkı Belirten Bağımsız. Ölçümler t-Testi

\begin{tabular}{lcccccc}
\hline Cinsiyet & $\mathbf{N}$ & $\overline{\mathbf{X}}$ & $\mathbf{S}$ & $\mathbf{s d}$ & $\mathbf{t}$ & $\mathbf{p}$ \\
\hline Kadin & 182 & 65,54 & 10,84 & 247 & 1,499 & \multirow{2}{*}{$\mathbf{1 3 5}$} \\
Erkek & 67 & 63,07 & 13,32 & 247 & & \\
\hline
\end{tabular}

Tablo 2'ye göre Türkçe öğretmeni adaylarının Türkçe dil bilinçlerinin cinsiyete göre farklılık arz etmediği görülmektedir $\left[\mathrm{t}_{(247)}=1,499, \mathrm{p}>, 05(\mathrm{p}=, 135)\right]$. Kadın öğretmen adaylarının puan ortalaması 65,54 iken erkek öğretmen adaylarının puan ortalaması 63,07'dir. Türkçe öğretmeni adaylarının Türkçe dil bilinci puanlarının birbirine yakın olduğu ve cinsiyete göre farklılık arz etmediği buradan da anlaşılmaktadır.

\section{Üçüncü Alt Probleme Yönelik Bulgular}

Çalışmanın üçüncü alt problemi, Türkşe ögretmeni adaylarmmn Türkşe dil bilincinin simf dürzylerine göre farkhllk arz edip etmediğine ilişkindir. Buna yönelik bulgular Tablo 3a ve 3b'de yer almaktadır.

Tablo 3a. Türkşe Ögrretmeni Adaylarmnn Simf Seviyelerine Göre Türkse Dil Bilinçleri İle İlgili Betimsel İstatistikler

\begin{tabular}{lccc}
\hline Okullar & $\mathbf{N}$ & $\overline{\mathbf{X}}$ & $\mathbf{S}$ \\
\hline 1. sinif & 68 & 60,92 & 1,52 \\
2. sinif & 26 & 65,61 & 2,31 \\
3. sinif & 59 & 10,53 & 1,37 \\
4. sinif & 96 & 11,58 & 1,11 \\
Toplam & 249 & 64,88 & 11,58 \\
\hline
\end{tabular}

Tablo 3b. Türkşe Ögretmeni Adaylarmm Simf Seviyelerine Göre Türkse Dil Bilinçleri Arasındaki Farkı Belirten Tek Faktörlü Varyans Analizi (One-Way Anova) Testi

\begin{tabular}{lcccccc}
\hline Varyansın kaynağı & Kareler toplamı & Sd & $\begin{array}{c}\text { Kareler } \\
\text { ortalamasi }\end{array}$ & $\mathbf{F}$ & $\mathbf{p}$ & Anlamlı fark \\
\hline Gruplararası & 1513,149 & 3 & 504,383 & 3,890 &, $\mathbf{0 1 0}$ & 1 .sinıf-3.sınıf \\
Gruplariçi & 31770,473 & 245 & 129,675 & & & 1. sinnf-4.sinıf \\
Toplam & 33283,622 & 248 & & & & \\
\hline
\end{tabular}

Tablo 3b’ye bakıldığında Türkçe öğretmeni adaylarının Türkçe dil bilincinin sınıf seviyelerine göre farklılık arz ettiği görülmektedir $[\mathrm{F}(3,245)=3,890, \mathrm{p}<, 05(\mathrm{p}=, 010)]$. Yani öğretmen adaylarının Türkçe dil bilinci, sınıf seviyelerine göre farklılaşmaktadır. Farkın hangi sınıflar arasında olduğunu bulmak amacıyla yapılan Tukey testinin sonuçlarına göre bu farkın 1.sınıf ile 3.sınıf; 1.sınıf ile 4.sınıf Türkçe öğretmeni adayları arasında olduğu görülmektedir. Bu farklılık, seviyesi daha iyi olan sinıfların lehinedir. Tablo 3a'da yer alan betimsel istatistiklerdeki ortalamalarda da bunu görmek mümkündür.

\section{Dördüncü Alt Probleme Yönelik Bulgular}

Çalışmanın dördüncü alt problemi, Türkşe ögretmeni adaylarmm Türkşe dil bilincinin anne eğitim durumlarna göre farklhlık arz edip etmediğine iliş̧kindir. Buna yönelik bulgular Tablo 4a ve 4b'de yer almaktadır.

Tablo 4a. Türkşe Öğretmeni Adaylarmnn Anne Eğitim Durumlarna Göre Türkese Dil Bilinci İle İlgili Betimsel Istatistikler

\begin{tabular}{lccc}
\hline Okullar & $\mathbf{N}$ & $\overline{\mathbf{X}}$ & $\mathbf{S}$ \\
\hline Okur-yazar değil & 81 & 62,81 & 1,50 \\
İköğretim mezunu & 109 & 65,79 & 0,99 \\
Ortaöğretim mezunu & 38 & 63,92 & 1,87 \\
Yükseköğretim mezunu & 21 & 69,90 & 1,55 \\
Toplam & 249 & 64,88 & 0,73 \\
\hline
\end{tabular}


Tablo 4b. Türkşe Öğretmeni Adaylarnnn Anne Eğitim Durumlarna Göre Türkşe Dil Bilinci Arasmdaki Farkı Belirten Tek Faktörlï Varyans Analiri (One-Way Anova) Testi

\begin{tabular}{lcccccc}
\hline Varyansın kaynağı & Kareler toplamı & Sd & $\begin{array}{c}\text { Kareler } \\
\text { ortalamasi }\end{array}$ & F & p & Anlamlı fark \\
\hline Gruplararası & 1000,681 & 3 & 333,560 & 2,531 & $\mathbf{0 5 8}$ & Okur-yazar değil- \\
Gruplariçi & 32282,942 & 245 & 131,767 & & Yükseköğretim \\
Toplam & 33283,622 & 248 & & & mezunu \\
\hline
\end{tabular}

Tablo 4b’ye bakıldığında Türkçe öğretmeni adaylarının Türkçe dil bilincinin anne eğitim durumlarına göre farklılaşmadığı ancak elde edilen $\mathrm{p}$ değerinin anlamlı farklılık değerine çok yakın olduğu görülmektedir $[F(3,245)=2,531, p>, 05(\mathrm{p}=, 058)]$. Yani öğretmen adaylarının Türkçe dil bilinci, annelerinin eğitim durumuna göre önemli bir farkllık arz etmekle birlikte bu farklılık istatistiksel olarak anlamlı değildir. Farklılığın anlamlılık sınırına çok yakın olması nedeniyle Games-Howell testinin sonuçlarına da bakılmış okur-yazar olmayanlarla yükseköğretim mezunları arasında anlamlı bir farklıllğın olduğu saptanmıştır. Bu farklılık yükseköğretim mezunlarının lehinedir (,009).

\section{Beşinci Alt Probleme Yönelik Bulgular}

Çalışmanın beşinci alt problemi, Türkege öğretmeni adaylarmn Türkşe dil bilincinin baba eğitim durumlarna göre farkhllk arz edip etmediğine ilişkindir. Buna yönelik bulgular Tablo 5a ve 5b’de yer almaktadır.

Tablo 5a. Türkşe Öğretmeni Adaylarmm Baba Eğitim Durumlarna Göre Türkşe Dil Bilinci İle İlgili Betimsel Istatistikler

\begin{tabular}{lccc}
\hline Okullar & $\mathbf{N}$ & $\overline{\mathbf{X}}$ & $\mathbf{S}$ \\
\hline Okur-yazar değil & 27 & 63,11 & 14,04 \\
İlköğretim mezunu & 112 & 65,28 & 10,51 \\
Ortaöğretim mezunu & 77 & 64,58 & 12,07 \\
Yükseköğretim mezunu & 33 & 65,70 & 12,08 \\
Toplam & 249 & 64,88 & 11,58 \\
\hline
\end{tabular}

Tablo 5b. Türkşe Ögrretmeni Adaylarmm Baba Ë̆̈itim Durumlarna Göre Türkşe Dil Bilinci Arasındaki Farke Belirten Tek Faktörlï Varyans Analizi (One-Way Anova) Testi

\begin{tabular}{lcccccc}
\hline Varyansın kaynağı & Kareler toplamı & Sd & $\begin{array}{c}\text { Kareler } \\
\text { ortalamasi }\end{array}$ & F & p & Anlaml fark \\
\hline Gruplararası & 130,865 & 3 & 43,622 &, 531 &, $\mathbf{8 0 9}$ & --- \\
Gruplariçi & 33152,757 & 245 & 135,317 & & & \\
Toplam & 33283,622 & 248 & & & & \\
\hline
\end{tabular}

Tablo 5b’ye bakıldığında Türkçe öğretmeni adaylarının Türkçe dil bilincinin baba eğitim durumlarına göre farkllılı arz etmediği görülmektedir $[\mathrm{F}(3,245)=, 531, \mathrm{p}>, 05(\mathrm{p}=, 809)]$. Yani öğretmen adaylarının Türkçe dil bilinci, baba eğitim durumlarına göre farklılaşmamaktadır. Tablo 5a'da yer alan betimsel istatistiklerdeki Türkçe dil bilinci puanlarının birbirine yakın olduğu ve baba eğitim durumlarına göre farklılık arz etmediği buradan da anlaşılmaktadır.

\section{Altınc1 Alt Probleme Yönelik Bulgular}

Çalışmanın altıncı alt problemi, Türkşe dil bilinci kavramınn Türkşe ögretmeni adaylar için ne anlam ifade ettiğine ilişkindir. Buna yönelik bulgular Tablo 6'da yer almaktadır. 
Tablo 6. Türkşe Dil Bilinci Kavrammmn Türkşe Öğretmeni Adaylar İ̧cin Ne Anlam İfade Ettiği

\begin{tabular}{|c|c|c|}
\hline No & Temalar & $f$ \\
\hline 1 & Türkçenin kurallarına uymak / Türkçenin doğru kullanılması & 58 \\
\hline 2 & Kimlik / benlik olarak görülmesi & 32 \\
\hline 3 & Dilimize / Türkçeye sahip çıkmak & 31 \\
\hline 4 & Milletin, devletin geleceği olarak görülmesi / Var olma sebebi & 27 \\
\hline 5 & Bilinçli olma hali / Farkındalık & 20 \\
\hline 6 & Türkçenin devamlılı̆̆1 & 8 \\
\hline 7 & Milli kültürü temsil etmesi & 8 \\
\hline 8 & Her şey olarak görülmesi & 6 \\
\hline 9 & Ana dilin farkında olmak & 6 \\
\hline 10 & Nitelikli bir iletişim & 6 \\
\hline 11 & Değerlerimizin farkında olmak / Değerlerimize sahip çıkmak & 5 \\
\hline 12 & Yabancı dillerden arınma & 5 \\
\hline 13 & Birlik olma / bir olma & 4 \\
\hline 14 & Bireyin kendini ifade edebilmesi & 3 \\
\hline 15 & Miras olarak kabul edilmesi & 3 \\
\hline 16 & Dilimize hâkim olma & 2 \\
\hline 17 & Bilinçli bireyler yetiştirmek & 1 \\
\hline 18 & Herkesin Türkçe konuşması & 1 \\
\hline 19 & Kişiliğin gelişimi & 1 \\
\hline 20 & Manevi bir değer & 1 \\
\hline
\end{tabular}

Tablo 6 incelendiğinde Türkçe öğretmeni adaylarından alınan görüşler doğrultusunda Türkçe dil bilinci kavramının kendileri için farklı anlamlara geldiği görülmektedir. Türkçe dil bilinci kavramı Türkçe öğretmeni adayları için en fazla "Türkscenin kurallarna uymak/Türkşenin doğru kullanılması" ( $\mathrm{f}=58)$ anlamlarına gelmektedir. Bunu "Kimlik/benlik olarak görülmesi" ( $\mathrm{f}=32)$ "Dilimize/Türkseye sahip çkmak" (f=31) "Milletin, devletin geleceği olarak görülmesi/Var olma sebebi" ( $\mathrm{f}=27)$ "Bilinçli olma hali/Farkandahk" ( $\mathrm{f}=20)$ temaları izlemektedir. Araştırma kapsamında bu soruya yönelik kimi Türkçe öğretmeni adaylarının görüşleri aşağıda verilmiştir:

"Benim için Türkşe dil bilinci, dilin doğru ve belli kurallar çerçevesinde kullanılmasıdır." (K191)

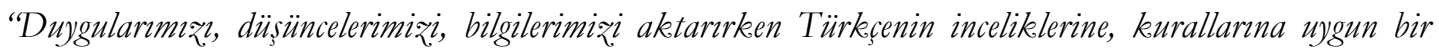
anlatım biçimi tercih ederek bunu kullanmak." (K12)

"Türkeseyi bilinçli bir şekilde kullanmak ve dili kurallarna uygun bir șekilde kullammm yayginlastırmak. Türkseye zarar verebilecek konusmalardan ve yanlss kullanmlardan kaçınmak.” (K50)

"Türkscyi imla kurallarm dikekate alarak ve içeriğe özen göstererek dilini en güzel şekilde kullanmast demek." (K77)

"Kurulan cümlelerde Türkse kelimelere ve dil kuralarna yer vermek ve bunu günlük hayatta kullanabilmek." (K167)

"Türkse dil bilinci benim için varlğğmın gerçekliğini ifade eder. Bir dile sabip olmak bir ülkeye sabip olmak her zaman var olmanin toplumsal yapı için gerekli maddelerindendir.” (K247)

\section{Yedinci Alt Probleme Yönelik Bulgular}

Çalışmanın yedinci alt problemi, Zaman ve teknolojinin ilerlemesiyle bireylerde Türkşe dil bilincinin zaynflayacağın düs̈̈̈n̈̈yor musunuz? Neden? sorusudur. Buna yönelik bulgular Tablo 7'de yer almaktadır.

Tablo 7. Türkse Öğretmeni Adaylarmin Zaman ve Teknolojinin Ilerlemesiyle Bireylerde Türkse Dil Bilincinin Zayıflayacağın Düsünüp Düs̆̈̈nmeme Durumlar

\begin{tabular}{clcc}
\hline No & & Temalar & $f$ \\
\hline 1 & Evet / Düşünüyorum & & 230 \\
2 & Hayır / Düşünmüyorum & 19 \\
\hline
\end{tabular}

Tablo 7 incelendiğinde Türkçe öğretmeni adaylarının büyük çoğunluğunun ( $\mathrm{f}=230$ ) zaman ve teknolojinin ilerlemesiyle bireylerde Türkçe dil bilincinin zayıflayacağını düşündüğü görülmektedir. Bireylerde Türkçe dil bilincinin zayıflayacağını düşünmeyen Türkçe öğretmeni adaylarının sayısı ise çok $\operatorname{azd} 1 \mathrm{r}(\mathrm{f}=19)$.

"Zaman ve teknolojinin ilerlemesiyle bireylerde Türkçe dil bilincinin zayıflayacağını düşünüyor musunuz? Neden?" sorusunun "Neden” kısmına yönelik bulgular Tablo 8 ve Tablo 9'da verilmiştir. 
Tablo 8. Türkşe Öğretmeni Adaylarını Zaman ve Teknolojinin İlerlemesiyle Bireylerde Türkçe Dil Bilincinin Zayflayacağın Düsünme Durumlarna (Evet/Düsünüyorum) Yönelik Gerekçeleri

\begin{tabular}{|c|c|c|c|}
\hline \multicolumn{2}{|c|}{ No } & Temalar & $f$ \\
\hline \multirow{19}{*}{1} & \multirow{19}{*}{$\begin{array}{l}\text { Evet / } \\
\text { Düşünüyorum }\end{array}$} & Yabanc1 sözcüklerin / dillerin fazla kullanılması & 64 \\
\hline & & Teknolojinin yaşamımızda daha fazla yer tutacak olması / Teknoloji faktörü & 61 \\
\hline & & Özenti / Popüler kültür & 23 \\
\hline & & Sosyal medya faktörü & 22 \\
\hline & & Teknolojik üretimde geri kalmamız & 15 \\
\hline & & Türkçenin kurallarına olan hâkimiyetin giderek azalması & 11 \\
\hline & & Küreselleşme & 10 \\
\hline & & Tembellik / Kolaya kaçma & 7 \\
\hline & & Kültürel yozlaşma & 6 \\
\hline & & Kitle iletişim araçlarının varlığı & 6 \\
\hline & & Sorgulamayan bir neslin oluşması / Bilinç eksikliği & 5 \\
\hline & & Toplumun giderek bunu kanıksaması & 5 \\
\hline & & Her şeyin tek tipe dönüşmesi/dönüşecek olması & 4 \\
\hline & & Türkçeye sahip çıkan insan sayısının az olması & 3 \\
\hline & & Türk Dil Kurumunun yeterince çalışmaması / Gelişmeleri geç takip etmesi & 3 \\
\hline & & İnsanlar arası iletişimin giderek zayıflaması & 3 \\
\hline & & Teknolojinin öneminin dilin önemini geçmesi & 2 \\
\hline & & Okuma alışkanlığının azalması & 2 \\
\hline & & Eğitimin niteliğinin giderek düşmesi & 1 \\
\hline
\end{tabular}

Tablo 8 incelendiğinde Türkçe öğretmeni adaylarının zaman ve teknolojinin ilerlemesiyle bireylerde Türkçe dil bilincinin zayıflayacağını düşünme durumlarına (evet/düşünüyorum) yönelik gerekçeleri verilmiştir. Türkçe öğretmeni adaylarına göre özellikle "Yabancı sözcüklerin/dillerin fąla kullanılması" ( $\mathrm{f}=64)$, "Teknolojinin yaşamımızda daha fazla yer tutacak olması/Teknoloji faktörü" ( $\mathrm{f}=61)$, "Özenti/ Popüler kültür” (f=23), "Sosyal medya faktörü" (f=22), "Teknolojik üretimde geri kalmamız” ( $\mathrm{f}=15)$, "Türkecenin kurallarna olan hâkimiyetin giderek azalması" ( $\mathrm{f}=11)$ gibi durumlar ilerde bireylerde Türkçe dil bilincinin azalmasına sebep olacaktır. Araştırma kapsamında bu soruya yönelik kimi Türkçe öğretmeni adaylarının görüşleri aşağıda verilmiştir:

“Evet, çünkü popüler kültür insanlar üzerinde önemli bir faktördür. Dil bilincimizi de etkileyecektir.” (K91)

"Evet, çünkü insanlar pasif hale gelmektedir. Bu da dikekatsizliği ilgisizlĭgi doğurduğundan dolayn iletişimsizlik artacağından beraberinde sönük ilgisiz bir dil kalacaktır.” (K63)

"Evet düsünüyorum. Cü̈nkü teknolojinin ilerlemesiyle dil çok kötü bir şekilde kullanlmaktadir. Yaz!m ve noktalama isaretlerine dikekat edilmemektedir." (K146)

"Kesinlikle düsünüyorum. Cü̈kü teknolojinin gelismesiyle özellikle sosyal medya kullamular dili bilinçsiz bir şekilde moda, ilgi çekme gibi çeşitli nerelerle Türkçeyi yanlsş kullanmaktadırlar ve bu bilinçsizlike bralla yaylmaktadır. Aynca teknolojinin gelişmesiyle küresel bir kültür ortaya çıkmıs ve Türkeçe birçok farkh dilinin adeta bir saldirisina maruz. kalmıstır." (K148)

"Evet. Diğer ülkeler teknolojide bizden önde. Bu yüzden biz onlarm teknolojilerine dâbil olunca onlarn kullandĭg kelimeler bizim dilimize geçiyor. Teknoloji arttıkça bu da artar.” (K225)

Tablo 9. Türkese Öğretmeni Adaylarmm Zaman ve Teknolojinin İlerlemesiyle Bireylerde Türkçe Dil Bilincinin Zayıflamayacağın Düsünme Durumlarna (Hayır/Düsünmüyorum) Yönelik Gerekçeleri

\begin{tabular}{|c|c|c|c|}
\hline No & & Temalar & $f$ \\
\hline \multirow{8}{*}{2} & \multirow{8}{*}{$\begin{array}{l}\text { Hayır / } \\
\text { Düşünmüyorum }\end{array}$} & Teknoloji ile dilin gelişiminin paralel olması & 4 \\
\hline & & Dile daha fazla sahip çıkılacağının düşünülmesi & 2 \\
\hline & & Toplumsal bilincin yükselecek olması & 2 \\
\hline & & Dil bilincinin aşılanacak olması & 2 \\
\hline & & Bireysel bir tercih olması & 2 \\
\hline & & Dilin gelecek kuşaklara aktarılması & 1 \\
\hline & & Duyarlı bir kesimin olması & 1 \\
\hline & & Okullarda verilen eğitimin nitelikli olması & 1 \\
\hline
\end{tabular}


Tablo 9 incelendiğinde Türkçe öğretmeni adaylarının zaman ve teknolojinin ilerlemesiyle bireylerde Türkçe dil bilincinin zayıflamayacağını düşünme durumlarına (hayır/düşünmüyorum) yönelik gerekçeleri verilmiştir. Türkçe öğretmeni adaylarına göre "Teknoloji ile dilin gelisiminin paralel olması" ( $\mathrm{f}=4)$, "Dile daha

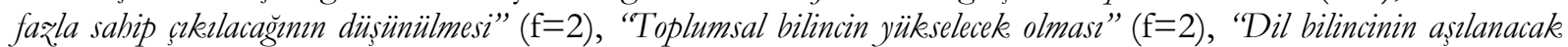
olması" ( $\mathrm{f}=2$ ) gibi durumlar ilerde bireylerde Türkçe dil bilincinin azalmasına engel olacaktır. Araştırma kapsamında bu soruya yönelik kimi Türkçe öğretmeni adaylarının görüşleri aşağıda verilmiştir:

"Hayır, çünkü dil gelecek kuşaklara aktarlır. Aktarldiğ için de bu bilinç az̧alma:." (K42)

"Hayır, çünkü teknoloji geliștikşe dil de dil bilinci de gelişir." (K69)

"Düș̈̈nmüyorum, şünkü bu bilins Türk milletine doğru bir șekilde aktarlmıs olursa zaman ve teknolojinin bir etkisi olama\%”" (K115)

"Düsï̈nmüyorum. Cünkë Türkse benim anadilim zaman ve teknoloji bir dili zaynflatmamali aksine daba çok sabip çıılmalidir dile. Çıılacaktır da" (K166)

\section{Tartışma, Sonuç ve Öneriler}

Türkçe öğretmeni adaylarının Türkçe dil bilinci düzeylerini çeşitli değişkenlere göre tespit etmeyi ve Türkçe dil bilinci ile ilgili görüşlerini belirlemeyi amaçlayan bu çalışmada çeşitli sonuçlara ulaşılmıştır. Araştırma sonuçlarına göre Türkçe öğretmeni adaylarının "yüksek düzeyde” Türkçe dil bilincine sahip oldukları tespit edilmiştir. Ulaşılan bu sonucun değerli olduğunu belirtmek gerekir. Üniversitede okuyan ve Türkçe öğretmenliği bölümünde öğrenim gören öğrencilerin dil bilinç düzeylerinin yüksek olması beklenir. Bulut ve Coşkun (2020, s. 10) tarafindan yapılan çalışmada Türkçe öğretmeni adaylarının büyük kısmı yüksek düzeyde dil bilincine sahip olduklarını belirtmişlerdir. Arslan ve Kılıç (2012, s. 802) Türkçe öğretmenleri ve öğretmen adayları ile yürüttükleri çalışma sonucunda Türkçe öğretmenleri ve öğretmen adaylarının Türkçe dil bilinç düzeylerinin iyi düzeyde olduğunu saptamışlardır. Alan yazında Türkçe ögretmenleri ve Türkçe öğretmeni adaylarının yanı sıra Türk dili ve edebiyatı öğretmen adaylarının dil bilinç düzeylerinin ele alındığı çalışmalar da bulunmaktadır. Tekşan ve Kanık Uysal’ın (2018, s. 269) çalışmasında Türk Dili ve Edebiyatı bölümünde öğrenim gören öğrencilerin Türkçe bilinç düzeylerinin yüksek olduğu sonucuna ulaşılmıştır. Bunların yanı sıra öğretim elemanlarının dil bilinç durumlarının araştırıldığı çalışmalar da yapilmıştır. Kızıltan ve Ersanlı’nın (2008, s. 48) çalışmasında öğretim elemanlarının genel olarak dil bilincine sahip oldukları saptanmıstır.

Çalışmada ulaşılan bir başka sonuç Türkçe öğretmeni adaylarının Türkçe dil bilinçlerinin cinsiyete göre farklılık arz etmediğidir. Kadın öğretmen adaylarının puan ortalaması 65,54 iken erkek öğretmen adaylarının puan ortalaması 63,07'dir. Türkçe öğretmeni adaylarının Türkçe dil bilinci puanlarının cinsiyet değişkenine göre birbirine yakın olduğu ve farklılık arz etmediği saptanmıştır. Hem kadın hem de erkek öğretmen adaylarının puanlarının birbirine yakın olması ve dil bilinç düzeylerinin yüksek olması önemli bir göstergedir. Erdem ve Eskimen (2019, s. 30) tarafindan yapılan çalışmada da kadın öğretmen adaylarının dil bilinci düzeylerinin erkek öğretmen adaylarına göre daha yüksek olduğu ancak bu durumun anlamlı farkın oluşmasını sağlamadığı tespit edilmiştir. Arslan ve Kılıç (2012, s. 805) yaptıkları çalışmalarında Türkçe öğretmenleri ile öğretmen adaylarının Türkçe bilinç düzeylerinin cinsiyete göre değişmediği sonucunu elde etmişlerdir.

Araştırmada Türkçe öğretmeni adaylarının Türkçe dil bilincinin sınıf seviyelerine göre farklılık arz ettiği tespit edilmiştir. Yani Türkçe öğretmeni adaylarının Türkçe dil bilinci, sınıf seviyelerine göre farklılaşmaktadır. Farkın hangi sınıflar arasında olduğunu bulmak amacıyla yapılan Tukey testinin sonuçlarına göre bu farkın 1.sınıf ile 3.sınıf; 1.sınıf ile 4.sınıf Türkçe öğretmeni adayları ve arasında olduğu görülmektedir. Bu farklılık, seviyesi daha iyi olan sınıfların lehinedir. Tekşan ve Kanık Uysal'ın (2018, s. 270) çalışmasında Türk Dili ve Edebiyatı bölümünde öğrenim gören öğrencilerin Türkçe Bilinç düzeyleri sınıf değişkeni bağlamında anlamlı bir farklılık göstermemiştir ancak öğrencilerin sınıf düzeyleri yükseldikçe Türkçe dil bilinç düzeylerinin de yükseldiği saptanmıştır. Erdem ve Eskimen'in (2019, s. 29) çalışmasında da öğretmen adaylarının sınıf düzeyleriyle birlikte ortalama dil bilinç puanlarında da bir yükseliş olduğu saptanmıştır.

Çalışma kapsamında Türkçe öğretmeni adaylarının Türkçe dil bilincinin anne ve baba eğitim durumlarına göre farklılaşıp farklılaşmadığı da incelenmiştir. Türkçe öğretmeni adaylarının Türkçe dil bilinçlerinin hem anne hem de baba eğitim durumlarına göre puanların birbirine yakın olduğu ve anlamlı farklılık göstermediği saptanmıştır. Baba eğitim durumlarında anlamlı farklılık bulunmamaktadır ancak 
baba eğitim durumu "yükseköğretim" olan Türkçe öğretmeni adaylarının puanlarının daha yüksek olduğu saptanmıştır. Anne ve babaların eğitim durumlarının, çocuklarını yetiştirme tarzlarının çocuklar üzerinde önemli bir etkisi vardır. "Ebeveynlerin çocukların ilk ve ebedi eğitmenleri oldukları ve erken yaşlarında onlarla ilgilenmelerinin onların öğrenmeleri üzerinde etkili olduğu” (Bruce, 2010, s. 7) düşünüldügünde bu bulgunun kayda değer olduğu söylenebilir. Pehrson ve Robinson (1990) ve Özel ve Zelyurt (2016) tarafından yapılan çalışmalarda da anne baba eğitim durumlarının çocukların iletişim ve dil becerilerini olumlu yönde etkilediği saptanmıştır.

Türkçe öğretmeni adaylarından alınan görüşlerde Türkçe dil bilinci kavramının kendileri için farklı anlamlara geldiği tespit edilmiştir. Türkçe dil bilinci kavramı Türkçe öğretmeni adayları için en fazla "Türkşenin kurallarna uymak/Türkşenin doğru kullanılması" ( $\mathrm{f}=58)$ anlamlarına gelmektedir. Türkçe dil bilinci kavramının "Kimlik/ benlik olarak, görülmesi" ( $\mathrm{f}=32)$ "Dilimize/Türkseye sahip çımak" ( $\mathrm{f}=31)$ "Milletin, devletin geleceği olarak görülmesi/Var olma sebebi" ( $\mathrm{f}=27$ ) "Bilincli olma hali/Farkindallk" ( $\mathrm{f}=20)$ olarak görülmesi de önemli bulgular arasındadır. Özellikle Türkçeye sahip çıkacak ve onu geliştirecek meslek gruplarından birinin Türkçe öğretmenleri olduğu düşünüldügünde öğretmen adaylarının bu bilinçte olmaları önemli bir bulgudur. Kocasavaş'ın (2007) “Türkçe eğitiminde (hatta diğer derslerde de) anadili şuuru ve zevkinin verilmesi, dilimizin anlaşı1ır, yaş seviyesine uygun, zengin ve güzel örneklerinin aktarılması dil bilincini geliştirecektir" değerlendirmesi çalışma kapsamında ulaşılan bulguyu destekler mahiyettedir. Türkçe dil bilinci kavramı, Türkçe öğretmeni adaylanınca kimlik/benlik, dilimize/Türkçeye sahip çıkmak ve milletin, devletin geleceği/var olma sebebi, miras olarak da görülmüsstür. Bu bulgular Türkçe öğretmeni adaylarının Türkçeyi sahiplenme noktasında önemli bir kaygı içinde olduklarını da göstermektedir. Zira "dil, bizim varlık sebebimizdir. Bunu asla unutmamalıyız." (Sinanoğlu, 2002, s. 57) ve "Türkçem benim ses bayrağım." (Fazıl Hüsnü Dağlarca) ifadeleri de tam da bu durumu yansıtmaktadır.

Araştırmada Türkçe öğretmeni adaylarının büyük çoğunluğunun zaman ve teknolojinin ilerlemesiyle bireylerde Türkçe dil bilincinin zayıflayacağını düşündüğü belirlenmiştir. Bireylerde Türkçe dil bilincinin zayıflayacağını düşünmeyen Türkçe öğretmeni adaylarının sayısı ise oldukça azdır. Türkçe öğretmeni adaylarının dil bilinci için ilerde yaşanabilecek sıkıntılanı, olumsuz durumları şimdiden görmesi de önemlidir. Türkçe öğretmeni adaylarının zaman ve teknolojinin ilerlemesiyle bireylerde Türkçe dil bilincinin zayıflayacağını düşünme gerekçeleri arasında "Yabancı sözcüklerin/dillerin fazla kullanılması", "Teknolojinin yaşammmızda daha fazla yer tutacak olmass/Teknoloji faktörü", "Özenti/Popüler kültür", "Sosyal medya faktörü" ,Teknolojik üretimde geri kalmamız", "Türksenin kurallarna olan hâkimiyetin giderek azalması" gibi tespitleri son derece önemlidir. Özellikle yabanc1 sözcüklerin/dillerin fazla kullanılması ve teknolojinin yaşamımızda daha fazla yer tutacak olması/teknoloji faktörü tespitleri birçok öğretmen adayı tarafindan vurgulanmıştır. Nitekim Kocasavaş (2007) da "erken yaşlarda daha ana dili bilinci oluşmadan yabancı dille eğitime başlanmasının (anaokulundan veya en iyi ihtimalle ilkokul 4. sınıftan itibaren), gençlerimizin dillerinde aksamalara yol açacağı"na vurgu yapmıştır. Göçer (2014) Türkçenin güncel sorunlarını tespit ettiği çalışmasında Türkçe öğretmeni adaylarının "Türkçenin özensiz ve yanlış kullanımı", "Yabancı sözcük kullanımı / yabancı dil tutkusu, özentisi” gibi sorunlarla karşı karşıya kaldığını saptamıştır. Benzer bir çalışmada da (Bağc1, 2012, s. 299) Türkçe öğretmeni adayları Türkçenin yaşadığı güncel sorunlar arasında en fazla 'Yabancı sözcüklerin dilimize egemen olması" ve "Yabancı sözcük kullanımının tercih edilmesi" durumlarını ifade etmişlerdir. Özellikle internet ortamındaki yabancı kökenli sözcük sayısının fazla olması ve bu sözcüklerin yerine Türkçelerinin kullanılmaması da önemli bir sorundur. Akçay ve Özcan (2012), çalışmalarında yabancı dil kökenli bilgisayar ve genel ağ sözcüklerinin Türkçeye yerleştiğini ve bunun dilimiz için önemli bir sorun teşkil edeceğini vurgulamışlardır. Kabadayı (2006) da çalışmasında "teknolojinin ve bilişim sektörünün bütün alanlarındaki terimlerin Türkçe olması veya Türkçeleştirilmesi gerektiği”"ni belirtmiştir. Uzuner ve Aktaş'ın (2016) çalışmasında ise öğretmen adaylarının kitle iletişim araçlarında fazlaca kullanılan ve bilgisayar teknolojisiyle ilgili yabancı kökenli kelimelerin Türkçe karşılıklarını büyük kısmının bilmediğini saptamışlardır. Bu çalışmada Türkçe öğretmeni adaylarına göre Türkçenin kurallarına olan hâkimiyetin giderek azalması ilerde bireylerde Türkçe dil bilincinin azalmasına neden olacaktır. Benzer bulguya Bağc1 (2012, s. 299) da ulaşmış ve dilin kurallarının bilinmemesinin Türkçenin yaşadığı önemli güncel sorunlardan olduğunu saptamıştır.

Türkçe öğretmeni adaylarının zaman ve teknolojinin ilerlemesiyle bireylerde Türkçe dil bilincinin zayıflamayacağını düşünme gerekçeleri azdır. Türkçe öğretmeni adaylarına göre "Teknoloji ile dilin gelişiminin paralel olması", "Dile daha fåla sabip çıılacağmnn düsünülmesi" , "Toplumsal bilincin yü̈kselecek olması", "Dil bilincinin aşılanacak olması" gibi durumlar ilerde bireylerde Türkçe dil bilincinin azalmasına engel olacaktır. Türkçe öğretmeni adayları arasında ilerde Türkçe dil bilincinin kaybolmayacağını düşünenlerin sayısı az 
olsa da bu kişilerin bulunması da kayda değerdir. Argunşah’n (2012, s. 84) “sorunun Türkçe değil bilinçsiz toplumda olduğunu, toplumun dil, kültür ve tarih konusunda yeterince bilinçlendirilmediğini, bunun her şeyden önce devlet politikası haline gelmesi gerektiŭgi"ni savunması önemli bir göstergedir.

Çalışmada ulaşılan bulgular bağlamında şu öneriler geliştirilmiştir:

- Dil bilinci kavramı sadece eğitimcilerin değil bir bütün olarak herkesin dikkat etmesi gereken bir husustur. Bu yüzden devlet kurumlarının bu hususta daha fazla işe koşması gerekir.

- Dil bilincinin özellikle Türkçe ders kitaplarında ve Türkçe öğretim programlarında detaylıca aktarilması gerekir.

- Özellikle teknolojik aletlerde kullanılan yabancı dillere ait sözcüklerin kontrol edilmesi ve Türkçe karşılıklarının kullanılması önerilmelidir.

\section{Etik Beyan}

“Türkşe Ögrretmeni Adaylarmın Türkşe Dil Bilinc Düzeylerinin Belirlenmesi: Bir Karma Yöntem Araștırması” başl1klı çalışmanın yazım sürecinde bilimsel kurallara, etik ve alıntı kurallarına uyulmuş; toplanan veriler üzerinde herhangi bir tahrifat yapılmamış ve bu çalışma herhangi başka bir akademik yayın ortamına değerlendirme için gönderilmemiştir. Bu çalışmada "Yükseköğretim Kurumları Bilimsel Araştırma ve Yayın Etiği Yönergesi” kapsamında uyulması istenilen bütün kurallara uyulmuştur. Yönergenin ikinci bölümünde yer alan "Bilimsel Araştırma ve Yayın Etiğine Aykırı Eylemler" başlığı alında ifade edilen fiillerden hiçbiri yapılmamıştır. Gerekli olan etik kurul izinleri Muş Alpaslan Üniversitesi Bilimsel Araştırma ve Yayın Etiği Kurulu'nun 26.05.2021 tarih ve 2021-12610 sayll kararı ile alınmıştır.

\section{Kaynakça}

Abu Radwan, A. (2005). The effectiveness of explicit attention to form in language learning. System, 33(1), 69-87.

Adalı, O. (1983). Ana dili olarak Türkçe öğretimi üzerine. Türk Dili Dil Öğretim Özel Sayısı, 47(379), 31-35.

Akçay, A. ve Özcan, M. F. (2012). Türkçe öğretmeni adaylarının bilgisayar ve genel ağ terimlerinin Türkçe karşıllklarını bilme yeterlikleri. Uluslararası Türkse Edebiyat Kültür Eg̈itim Dergisi, 1(4), 151-161.

Arslan, A. ve Kilıç, Y. (2012). Türkçe öğretmenleri ile öğretmen adaylarının Türkçe bilinç düzeyleri (Ağrn ili örneklemi). Turkish Studies International Periodical for the Languages, Literature and History of Turkish or Turkic, 7(4), 799-806.

Ateş, K. (2010). Öğretemediğimiz Türkçe. Ankara: İmge Kitabevi.

Aydeniz, S. ve Haydaroğlu, M. (2021). Dört temel dil becerisi alanında yapılan lisansüstü tezlerin bibliyometrik analizi. Türkiye Egitim Dergisi, 6(1), 200-216.

Baskın, S. ve Demir, Z. (2017). Türkçenin zenginliğgi ve ana dili bilincinin ortaokullarda kazandırılması: 5. sınıf örneği. Errincan Üniversitesi Ë̆itim Fakültesi Dergisi, 19(2), 173-194.

Birol, İ. (2015). Bireyde dil bilinci. Littera Turca Journal of Turkish Language and Literature, 1(2), 33-44.

Borg, S. (1994). Language awareness as a methodology: implications for teachers and teacher training. Language Awareness, 3 (2), 61-71.

Bruce, T. (2010). Early chidhood: A guide for studsents (2nd Edition). London: Sage

Bulut, K. ve Coşkun, H. (2020). Türkçe öğretmeni adaylarının dil bilincinin belirlenmesi. Yü̈̌üncü Yal Üniversitesi Ë̈itim Fakïltesi Dergisi, 17(1), 1128-1152.

Creswell, J. W. ve Plano Clark, V. L. (2014). Karma yöntem araşttrmalarn (Çev. Edt: Y. Dede ve S. B. Demir). Ankara: Anı Yayınlar1

Demir, Z. (2016). Sözcïle ögretimi yoluyla ortaokullarda Türkse dil bilincinin kazandrrlmast (Yüksek Lisans Tezi). Gaziosmanpaşa Üniversitesi, Eğitim Bilimleri Enstitüsü, Tokat.

Demirbağ, İ. (2002). Türkçe reklam bildirilerinde kullanılan yabancı sözcükler. C.Ü. Sosyal Bilimler Dergisi, 26 (1), 125134.

Erdem, C. ve Eskimen, A. D. (2019). Türk dili ve edebiyatı öğretmen adaylarının Türkçe bilinci üzerine bir araştırma. Mehmet Akif Ersoy Üniversitesi Eg̈itim Fakültesi Dergisi, 49, 23-27.

Eryılmaz, R. (2017). Milli kimlik unsuru olarak Türkçe ve Türkçenin güncel sorunları. 11 Eylül 2021 tarihinde https://www.academia.edu/35451939/M\%C4\%B0LL\%C4\%B0_K\%C4\%B0ML\%C4\%B0K_UNSURU_OLA

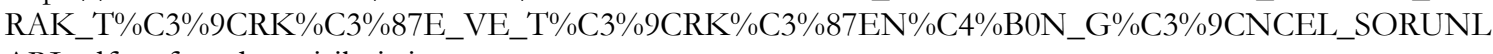
ARI.pdf sayfasından erişilmiştir.

Gass, S., Svetics, I. ve Lemelin, S. (2003). Differential effects of attention. Language Learning, 53(3), 497-545.

Göçer, A. (2013). Türkçe öğretmeni adaylarına göre Türkçenin güncel sorunları. Adiyaman Üniversitesi Sosyal Bilimler Enstitiisü Dergisi Türksenin Eğitimi Ögretimi Özel Sayısı, 6 (11), 491-515.

Göçer, A. (2014). Öğretmen adaylarının Türkçenin kullanımına ilişkin görüşleri: fenomenolojik bir analiz. Milli Eğitim, 43(203), 23-36.

İpek, B. (2015). Bireyde dil bilinci. Journal of Turkish Language and Literature, 1(2), 33-44.

Kaplan, M. (1996). Türk dili. Milli Ë̈itim Dergisi, 129. 
Kırkkılıç, A. ve Ulaş, A. H. (2003). Türkçe öğretiminde kelimeler dünyası. Türklük Bilimi Araştırmalar -Türkçenin Öğretimi Özel Sayısı, 13, 93-100.

Kızıltan, N. ve Yangın Ersanlı, C. (2008). Üniversite öğretim elemanlarının dil bilinci ve Türkçe kullanım duyarlılığı. Ondokuz. Mayıs Üniversitesi Ë̆itim Fakültesi Dergisi 25, 39-50.

Kocasavaş, Y. (2007). Türkçe eğitiminde dil şuuru zevkinin anlam ve önemi ders kitaplarında metinlerle desteklenmesi . Presented at the 38. Icanas, Ankara.

Kolaç, E. (2008). Sınıf öğretmeni adaylarının anadilimizin yaşadığı sorunlara ilişkin farkındalıkları görüş ve önerileri. Uluslararasi Sosyal Arastirmalar Dergisi, 1/5, s.441.

Leow, R. (1997). Attention, awareness and foreign language behaviour. Language Learning, 47(3), 467-505.

Özdemir, E. (1983). Ana dili olarak Türkçe öğretimi. Türk Dili Dil Öğretim Ö̌rel Sayısı, 379(380), 18-30.

Özel, E. ve Zelyurt, H. (2016). Anne baba eğitiminin aile çocuk ilişkilerine etkisi. Sosyal Politika Calışmalarn Dergisi, (36), 9-34.

Pehrson, K. L. ve Robinson, C. C. (1990). Parent education: Does it make a diference? Child Study Journal, 20(4), 221 236.

Robinson, M. (2005). Metalanguage in L1 English-speaking 12-year-olds: Which aspects of writing do they talk about? Language Awareness, 14(1), 39-55.

Rosa, E. ve O’Neill, M. (1999). Explicitness, intake and the issue of awareness: Another piece of the puzzle. Studies in Second Language Acquisition, 22 (4), 511-566.

Sever, S. (2001). Öğretim dili olarak Türkçenin sorunları ve öğretme öğrenme sürecindeki etkili yaklaşımları. Ankara Üniversitesi Eğitim Fakültesi Dergisi, 34(1), 11- 22.

Sinanoğlu, O. (2002). Bye Bye Türkese (4. Baskı). İstanbul: Otopsi Yayınları.

Şenyuva, E., Ertüzün, F., Turhan, K. ve Demir, N. (2017). Türk diline ilişkin sorunlar, çözüm önerileri ve Türkçe bilinci: kuşaklararası karşılaştırma. Uluslararası Türkşe Edebiyat Kültür Ë̈itim Dergisi, 6(3), 1384-1397.

Taşkesenlioğlu, L. (2020). Eski Türk edebiyatında Türk dili bilinci ve zevki. Milli Eğitim Dergisi, 49(226), 371-399.

TDK Güncel Türkçe Sözlük. Bilinç. 11 Eylül 2021 tarihinde https://sozluk.gov.tr/sayfasından erişilmiştir.

Tekşan, K. ve Kanık Uysal, P. (2018). Türk dili ve edebiyatı bölümünde okuyan öğrencilerin Türkçe bilinç düzeyleri. Milli Eğitim, 47(218), 263-274.

Temizyürek, F. (2008). Türkçe öğretmen adaylarının demografik özellikleri. Türk Eğitim Bilimleri Dergisi, 6(4), 663-692. Yaman, H. (2011). Türkçe bilinci ölçeği: geçerlik ve güvenirlik çalışması. Türk Eğitim Bilimleri Dergisi, 9(1), 151-167.

Yıldırım, A. ve Şimşek H. (2006). Sosyal bilimlerde nitel araştırma yöntemleri. Ankara: Seçkin Yayıncılık.

\section{EXTENDED ABSTRACT}

Language is a living thing. Its evolution depends on numerous factors, such as cultural, economic, technological, political, and social developments (Demirbağ, 2002, p. 126). These factors also affect language awareness. Turkish teachers play a key role in ensuring that people develop language awareness and put in the effort to preserve their language. Therefore, this study investigated Turkish teachers' awareness of the Turkish language based on different variables (gender, grade level, and parents' education) and looked into their views on the topic.

The sample consisted of 249 first-, second-, third, and fourth-year preservice Turkish teachers from four public universities. Participation was voluntary. The study adopted a mixed research design (qualitative and quantitative). Data were collected using two instruments. The quantitative data were collected using the 17-item Turkish Consciousness Scale (TCS; total score: 17 to 85) developed by Yaman (2011). The qualitative data were collected using an Opinion Form developed by the researchers. All data were collected online (Google Forms and email) due to the COVID-19 pandemic. The data were analyzed using the Statistical Package for Social Sciences (SPSS, v. 21.0). The qualitative data were analyzed using content analysis.

The first research question was, "How aware are participants of the Turkish language?" Participants had a mean TCS score of 64.88. Most participants agreed with the TCS statements, indicating that they were highly aware of Turkish.

The second research question was, "Is there a difference in Turkish language awareness between male and female participants?" Female and male participants had a mean TCS score of 65.54 and 63.07, respectively. The results showed that gender did not affect participants' awareness of Turkish.

The third research question was, "Does participants' Turkish language awareness differ by grade level?" The results showed that participants' Turkish language awareness differed by grade level. The Tukey test revealed that third- and fourth-year participants were more aware of Turkish than first-year participants. 
The fourth research question was, "Does participants' Turkish language awareness differ by mother's education?" The results showed no significant difference in participants' Turkish language awareness based on their mother's education level. However, the p-value was very close to the significance level. In other words, participants' Turkish language awareness differed by their mothers' education levels, but the difference was statistically insignificant. A Games-Howell test was performed because the p-value was very close to the significance level. The results showed that participants whose mothers had a bachelor's degree were more aware of Turkish than those whose mothers were illiterate (.009).

The fifth research question was, "Does participants' Turkish language awareness differ by father's education?" The results showed that participants' Turkish language awareness did not differ by their father's education.

The sixth research question was, "What does 'Turkish language awareness' mean to participants?" Participants stated that it meant different things to them. Most participants stated that Turkish language awareness meant "following the grammatical rules/using Turkish correctly" ( $\mathrm{f}=58)$, followed by "seeing it as part of identity/self" ( $\mathrm{f}=32$ ), "protecting our language/Turkish" ( $\mathrm{f}=31)$, "seeing it as the future of the nation and the state/Reason for existence" ( $\mathrm{f}=27)$, and "consciousness/awareness" ( $\mathrm{f}=20$ ).

The seventh research question was, "Do you think time and advances in technology will make people less and less aware of Turkish? If so, why?" Most participants ( $\mathrm{f}=230$ ) stated that they thought that time and advances in technology would make people less and less aware of Turkish. Only nineteen participants disagreed with it.

Participants believed that time and advances in technology would make people less and less aware of Turkish due to six reasons. First, Turkish people will use foreign words and languages more $(\mathrm{f}=64)$. Second, technology will be a greater part of our lives $(\mathrm{f}=61)$. Third, some Turkish people aspire to others and succumb to popular culture $(\mathrm{f}=23)$. Fourth, social media has a great influence on people $(\mathrm{f}=22)$. Fifth, we are technologically backward $(\mathrm{f}=15)$. Sixth, people know less and less about the grammar rules of Turkish ( $\mathrm{f}=11)$.

Nineteen participants expressed four reasons for why they did not think that time and advances in technology would make people less and less aware of Turkish. First, technology and language evolve at the same time $(\mathrm{f}=4)$. Second, people will hold onto Turkish more and more $(\mathrm{f}=2)$. Third, Turkish society will become more aware of Turkish $(\mathrm{f}=2)$. Fourth, people will be inculcated with language awareness $(\mathrm{f}=2)$. 